\title{
PRODUCTION OF BIODIESEL FROM WASTE VEGETABLE OIL USING A BENCH SCALE STIRRED VESSEL
}

\author{
M. A. Mosallam ${ }^{(1)}$, S. A. Tayel $^{(1)}$, \\ A. K. Zaalouk $^{(2)}$ and A. M. Mousa ${ }^{(3)}$
}

\begin{abstract}
This study aims to the production of biodiesel from a waste vegetable oil (WVO) using methyl alcohol and sodium hydroxide. The oil used is a mixture of soybean oil and sunflower with ratio 1:1. This oil is reminder of frying process. The study included the stirred vessel operating conditions and relative dimensions. The study was carried out under batch system using a bench scale stirred vessel. The study ended by: the ratio between the reactants; oil: alcohol: catalyst $=100 \mathrm{~cm}^{3}: 25 \mathrm{~cm}^{3}: 1$ g, $500 \mathrm{rpm}$ stirring speed and $15 \mathrm{~min}$ stirring time. The production is carried out under ambient temperature given that this temperature is $30^{\circ}$ $C$ or more. Volume of the batch has no detectable effect on the production. The stirred vessel used for the production is without baffles.

Relating to the diameter of the vessel " $D$ " diameter of the impeller was $1 / 2 \mathrm{D}$, clearance $1 / 5.3 \mathrm{D}$ and width of impeller $1 / 8 \mathrm{D}$.
\end{abstract}

\section{INTRODUCTION}

7 he global supply of petroleum and natural gas from the conventional resources is unlikely to meet the growth in demand

1 of energy, Lean (2007). The predicted shortage, increasing cost and unavailability of petroleum diesel all over the world has encouraged the search for renewable replacement for petroleum diesel. This search resulted in an alternative fuel called "biodiesel". Biodiesel is alkyl ester of fatty acids made by a transesterification of vegetable oils or animal fats, West et al. (2008). Some problems, associated with the production of biodiesel, are its inherent higher price. The higher price can be offset by the use of less expensive feedstock such as waste vegetable oils "WVO". The production of biodiesel from WVO offers a triple-facet solution: economic, environmental and waste management, Refaat (2010).

(1). Prof. of Ag. Eng. - Fac. of Ag. Eng. - Cairo - Al-Azhar Univ.

(2). Assoc. Prof. of Ag. Eng. - Fac. of Ag. Eng. - Cairo - Al-Azhar Univ.

(3). Assist. Lecturer of Ag. Eng. - Fac. of Ag. Eng. - Cairo - Al-Azhar Univ. 
The goal of this research is to establish specifications required for the production of biodiesel from WVO using a bench scale stirred vessel under batch system.

\section{REVIEW OF LITERATURE}

Production of Biodiesel occurs throughout a chemical reaction called transesterification. The transesterification reaction is the process by which fatty acids (e.g., vegetable oil or animal fat) is reacted with alcohol that is usually methanol or ethanol in the presence of a catalyst usually a base such as sodium hydroxide or potassium hydroxide. The transesterification process is reversible. The reactants are centrifuged to result in the biodiesel (as main product) and glycerin (as a by-product), which is allowed to settle under gravity, the upper layer of the products consists of crude biodiesel and the bottom layer consists of crude glycerin, the crude biodiesel is separated from glycerol then purified, Ahmad et al. (2009), Shoukry and Mosallam (2010) and Reyes et al. (2010).

Biodiesel is an oxygenated (contains $10-11 \%$ by weight), has very good lubricating properties significantly better than petroleum diesel which can prolong engine's life, has higher cetane number and higher flash point leading to safer handling and storage, Biodiesel has no sulfur content and approximately $78 \%$ less emissions (carbon dioxide and nitrogen oxides) compared to petroleum diesel. So, biodiesel is environmental friendly alternative to automotive fuel. Biodiesel can be easily blended with petroleum diesel and its use does not require any major modifications in engine. However, some problems, associated with biodiesel, are high price (The higher price can also be offset by the use of less expensive feedstocks such as waste oils, (e.g., used frying oils) and slightly increased nitrogen oxides in exhaust emissions, Lean (2007) and Arjun et al. (2008). The total consumption of vegetable oil in Egypt was $1.263 \mathrm{G} \mathrm{kg}$ in 2012 according to Food Balance Sheet (2012).

Morais et al. (2010) mentioned that alcohols such as methanol, ethanol or butanol can be used in the transesterification process and the resulting esters are named respectively, methyl, ethyl or butyl esters and so on. It is reported that yield of alcohols esters was the highest with methanol. 
Methanol is the alcohol most commonly used industrially due to its low-cost relatively to the other alcohols, high reactivity and more available. Shoukry and Mosallam (2010) used sunflower oil and methanol to produce biodiesel. The methanol was used with ratio $22.5 \%$ v/v to oil. Sarantopoulos et al. (2009) carried out the transesterification reaction using $25 \% \mathrm{v} / \mathrm{v}$ from methyl alcohol to oil (6:1 molar ratio) to produce biodiesel from curd palm oil. Math and Irfan (2007) reported that the maximum methyl ester yield was found to be at methanol 35\% v/v while using restaurant waste oil. Schuchardt et al. (1998) mentioned that the catalysts are base, acid, or enzyme; the base-catalyzed (sodium hydroxide or potassium hydroxide) gives a better conversion in a relatively short time. Meng et al. (2008) carried out transesterification process of WVO and used sodium hydroxide. They reported that $1 \% \mathrm{wt}$. $\mathrm{NaOH}$ to oil is the optimum concentration.

The production of biodiesel increases with increasing the reaction temperature according to, Ahmad et al. (2009) and Math et al. (2010). Meanwhile; Encinar et al. (2010) and Kuwornoo and Ahiekpor (2010) reported that the temperature has no detectable effect on the production of biodiesel. Therefor; room temperature is considered to be the optimum temperature for this process. Also Encinar et al. (2010) reported that the production of biodiesel was $96.3 \%$. This yield was obtained at room temperature $20^{\circ} \mathrm{C}$.

The alcohol and the oil are not miscible and need a vigorous mixing to allow the transesterification process to start, as mentioned by Meher et al. (2006). Shoukry and Mosallam (2010) produced biodiesel from sunflower oil under four stirring speeds: 250, 500, 750 and $1000 \mathrm{rpm}$. For each stirring speed, five reaction times were used: 10, 20, 30, 40 and 50 min. The optimum stirring speed for the production of biodiesel was 750 rpm and optimum reaction times were 40 and $50 \mathrm{~min}$. Leung and Guo (2006) mentioned that the excess reaction time does not increase the conversion but favors the backward reaction which results in a reduction of product yield; and reported too that the optimal reaction for the transesterification of WVO could be achieved at $60^{\circ} \mathrm{C}$ for a reaction time of $20 \mathrm{~min}$. Guo et al. (2002) mentioned that $30 \mathrm{~min}$ reaction time under 
$70^{\circ} \mathrm{C}$ reaction temperature are suitable for the production of biodiesel from WVO. Arévalo et al. (2008) produced biodiesel from virgin oil under $65^{\circ} \mathrm{C}, 600 \mathrm{rpm}$ stirring speed and $30 \mathrm{~min}$ stirring time. Math and Irfan (2007) used WVO to produce biodiesel and reported $55^{\circ} \mathrm{C}$ reaction temperature and $90 \mathrm{~min}$ reaction time. Math et al. (2010) used a mixture of $75 \% \mathrm{WVO}$ and $25 \%$ pig fat oil under $65^{\circ} \mathrm{C}$ and reaction time of 90 min. Ma et al. (1998) used edible beef tallow under reaction temperature $65^{\circ} \mathrm{C}$ and samples were taken at the beginning of the reaction $(0 \mathrm{~min})$ and after $1,2,3,5,7,9,13,15,20,30,45$, and 60 min during the transesterification process. The production of beef tallow methyl esters was complete after about $15 \mathrm{~min}$. Pinzi et al. (2011) produced biodiesel from sunflower oil, maize oil, olive oil, linseed oil, palm oil and coconut oil under agitation of $1100 \mathrm{rpm}$ and time reached $120 \mathrm{~min}$. Vicente et al. (2004) used each of salmon oil and sunflower oil. The reaction was carried out at $65^{\circ} \mathrm{C}$ and $600 \mathrm{rpm}$ stirring speed. El-Diwani et al. (2009) used jatropha oil and reported a reaction temperature of $65^{\circ} \mathrm{C}$ for $60 \mathrm{~min}$.

McCabe et al. (1993) mentioned that the liquids are most often agitated in some kind of tank or vessel, usually cylindrical in form and with a vertical axis. Tatterson (1991) pointedout the dimensions of a standard reactor (standard stirred tank), as shown in figures (1), cited from Jakobsen et al. (2013).

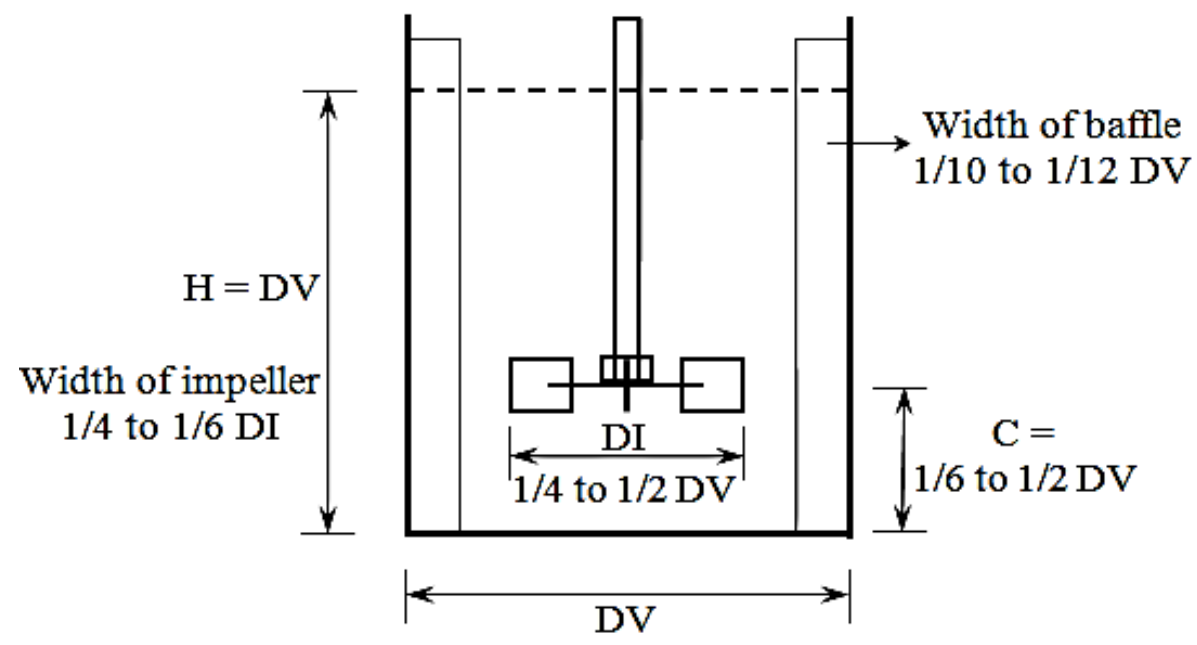

Fig. (1). Standard tank and Rushton impeller geometry, Tatterson (1991), cited from Jakobsen et al. (2013). 
Jakobsen et al. (2013) mentioned that the standard geometry stirred tanks are important for: minimizing the cost, determining the flow pattern, minimizing the power consumption and scaling up a process from laboratory to industrial plant scale. However, standard geometry is not the optimum geometry for all process in stirred tank but can viewed as reference geometry and as a point of departure for further studies.

\section{MATERIALS AND METHODS}

The used waste vegetable oil "WVO" is originally a mixture of two virgin vegetable oils: soybean oil and sunflower "with ratio 1:1". This oil was used in frying either domestic food (falafel فلافل, potatoes, eggplant, cauliflower... etc.) from 3 to 5 times or frying fish for once. Methyl alcohol was used for the production of biodiesel. The purity of methyl alcohol was $99.8 \%$ and molecular mass is $32.04 \mathrm{~g} / \mathrm{mol}$. The catalyst used was sodium hydroxide. The used sodium hydroxide was in shape of pellets, minimum assay was $97 \%$ and molecular mass $40 \mathrm{~g} / \mathrm{mol}$.

The biodiesel was produced under a bench scale using two units; the first unit was made from unplasticized polyvinyl chloride (PVC) with capacity of $0.5 \mathrm{~L}$ (Fig. 2) and this unit was used for the experiments on suitable ratios of reactants (WVO, methyl alcohol and sodium hydroxide) for the production. The PVC unit was also used to study the effect of stirring speed and stirring time. The second unit was made from stainless steel (SS) with capacity of 0.7 L (Fig. 3) and was dedicated for the experiments of effect of heating, volume of reactants on the production of biodiesel and was used for other experiments to investigate the suitable dimensions required for a cylindrical reactor of height equal to its diameter for the production of biodiesel (type of stirrer, clearance between axis of impeller and bottom of the stirred vessel, diameter and width of impeller and effect of a baffle).

Figure (3) shows the SS stirred vessel used for the production of biodiesel. A body of the vessel is a cylindrical pipe (4 mm thickness, 88 mm external diameter and its height $140 \mathrm{~mm}$ ) with a welded bottom and a welded upper flange in addition to a lid ( $5 \mathrm{~mm}$ thickness). The lid is attached to the pipe flange by means of 8 screws. A thermal gasket with 5 
$\mathrm{mm}$ thickness was put between the flange and the lid. This thermal gasket was used to tighten the vessel against the evaporation of the reactants. The reaction vessel was supplied with an external electrical heater and a thermostat. The vessel was constructed to bear a pressure of 4 bar, the capacity of the reaction vessel is 0.7 liter as a total volume. The vessel was equipped with a paddle stirrer.

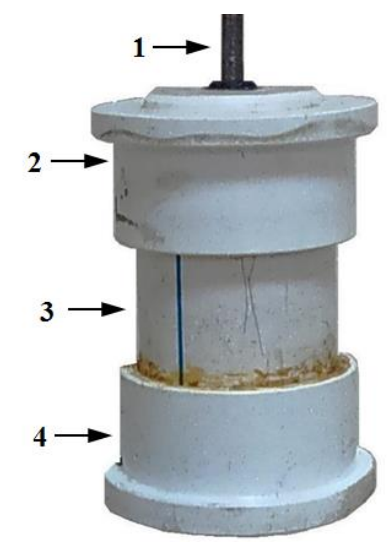

(1) Stirrer shaft, (2) Lid, (3) Cylindrical pipe and (4) Bottom.

Fig. (2). The PVC stirred vessel.
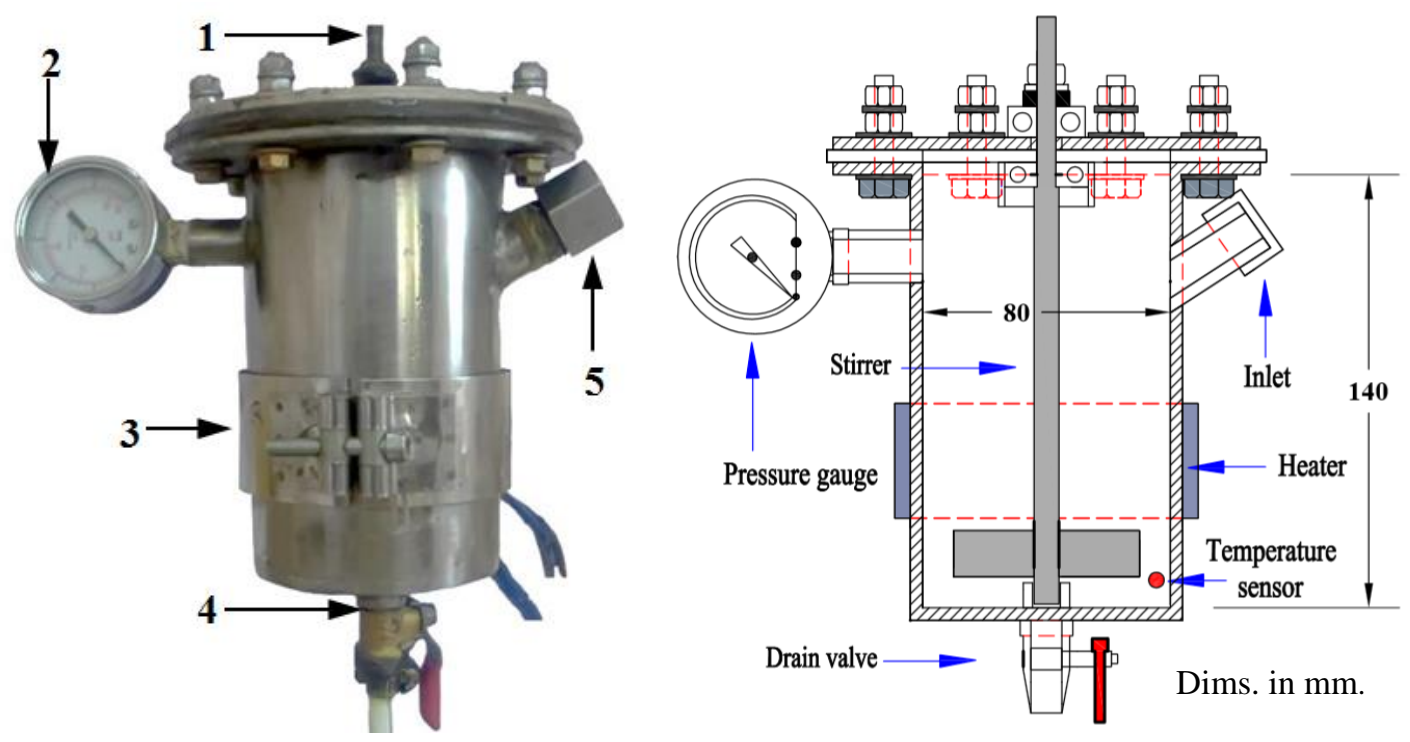

(1) Stirrer shaft, (2) Pressure gauge, (3) Heater, (4) Drain valve and (5) Inlet Fig (3). The SS stirred vessel. 
Alcohol to oil ratio was studied for 10, 20, 25, 35, 50, 60, 75 and 100\% $(\mathrm{v} / \mathrm{v})$. Sodium hydroxide to oil concentration was studied for $0.5,1$ and $1.5 \%$ (w/v). Stirring speed was studied for 250, 500, 750 and $1000 \mathrm{rpm}$. Each stirring speed was studied under five stirring times: 1, 5, 15, 30, 60 and $90 \mathrm{~min}$. The previously mentioned experiments were run using 100 $\mathrm{cm}^{3}$ of WVO. The results obtained from the PVC unit were applied for the experiments on the SS (stainless steel) unit.

Production of biodiesel was studied (using SS unit) under room temperature (30.5), in addition to 40,50 and $60^{\circ} \mathrm{C}$ using $300 \mathrm{~cm}^{3}$ of WVO. Effect of volume of the reactants on the production of biodiesel was investigated (SS unit) using: 200, 300, 400, 500 and $600 \mathrm{~cm}^{3}$.

The following experiments were carried out (SS unit) in the given order: (1) type of stirrer: Three types of stirrers were used: Rushton, Paddle and Blade, (see, Fig. 4), (2) Clearance: between axis of impeller and bottom of the vessel ratios of $1 / 5.3,1 / 2.3$ and $1 / 1.5$, (3) Impeller diameter: to vessel diameter of $1 / 4,1 / 3.2,1 / 2.7,1 / 2,1 / 1.6$ and 1/1.3, (4) Impeller width: to vessel diameter of 1/16, 1/10.7, 1/8, 1/6.4 and 1/5.3, and (5) Existence of a baffle: baffle width to vessel diameter: 1/16, 1/10.7 and 1/8. $320 \mathrm{~cm}^{3}$ of WVO were used for testing the previously mentioned dimensions.

(A)

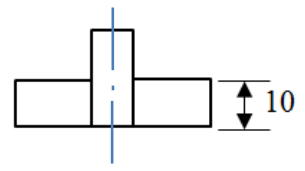

Elevation view

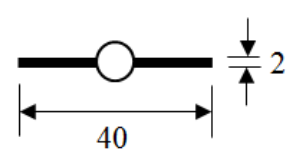

Plan view
(B)
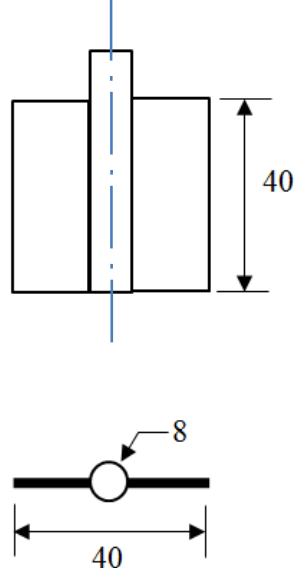

40
(C)
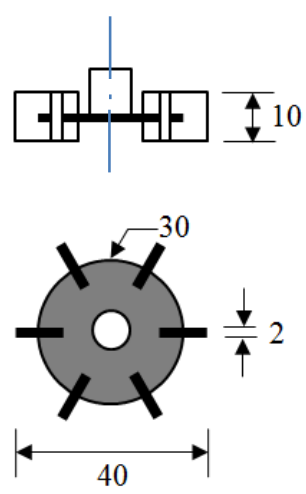

Dims. in mm.

(A) Paddle, (B) Blade and (C) Rushton.

Fig. (4).The three impellers used for the production of biodiesel. 
Ratios for each tested specification were chosen to be near the standard corresponding given ones for a stirred tank reactor. For each of the previously mentioned experiments, the obtained result was taken into consideration for the subsequent once. The crude biodiesel produced from each of PVC and SS units was separated from glycerol and washed from soap using tap water. For each experiment, three replicates were tried.

\section{RESULTS AND DISCUSSION}

Effect of the methanol to WVO percent on the biodiesel production:

Figure (5) shows that till a percent of methanol of $25 \%$, the production of biodiesel increases and reaches maximum. For a percent greater than $25 \%$, the production of biodiesel decreases. For a percent greater than $50 \%$ the reaction fails. Percent of $25 \%$ of methanol for the production is recommended by Sarantopoulos et al. (2009).

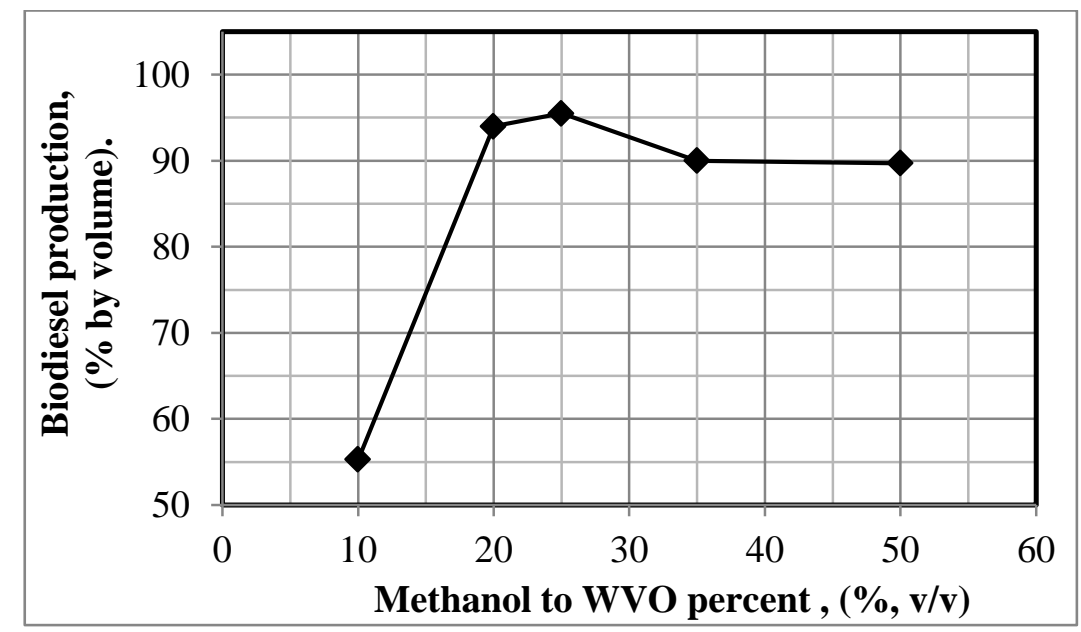

Fig. (5): The relationship between the production of biodiesel and methanol to WVO percentage.

\section{Effect of catalyst concentration on the produced biodiesel:}

Table (1) indicates that the concentration of the catalyst (related to volume of WVO) is a case of sensitivity. Concentration of $\mathrm{NaOH}$ of 1 gram per $100 \mathrm{~cm}^{3}$ of oil gives a reasonable production of biodiesel. This agrees with Encinar et al. (2005). At 1.5 concentration of $\mathrm{NaOH}$ to oil, the reaction fails; this agrees with Ugheoke et al. (2007). 
Table (1): The produced biodiesel under concentrations of $\mathrm{NaOH}$.

\begin{tabular}{lccc}
\hline Concentration of catalyst, $(\%, w / v)$. & 0.5 & 1.0 & 1.5 \\
\hline Biodiesel production, $(\%$, by volume). & 53.3 & 95.7 & ---- \\
\hline
\end{tabular}

Effect of stirring speed and stirring time on the produced biodiesel:

Figure (6) shows the relationship between production of biodiesel and four tested stirring speeds under the six tested times. The curves of times of the figure may be analyzed as follows:

(1)The curve which represents $90 \mathrm{~min}$ (dots) has the lowest values of the produced biodiesel. So 90 min time of stirring is not recommended for the production of biodiesel under the tested speeds.

(2)The two curves $1 \mathrm{~min}$ and $5 \mathrm{~min}$ (rhombus and squares, respectively) do not give a certain trend for the production of biodiesel. So, the two times $1 \mathrm{~min}$ and $5 \mathrm{~min}$ were discarded when producing biodiesel under each of the tested speeds.

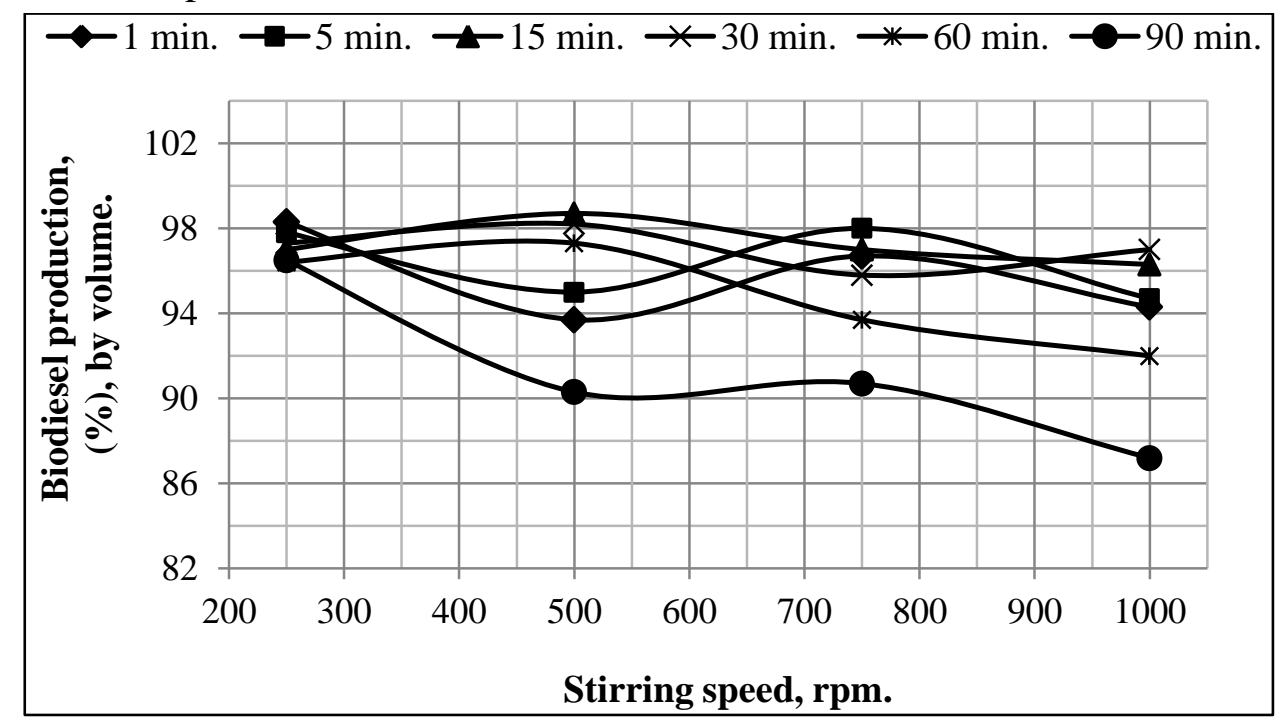

Fig. (6): The relationship between biodiesel production and stirring speed under six stirring times.

(3)For the three curves $15 \mathrm{~min}, 30 \mathrm{~min}$ and $60 \mathrm{~min}$ (triangle, $\mathrm{x}$ and asterisk), the production of biodiesel increases then decreases with the stirring speed. This is similar to the results obtained Shoukry and mosallam (2010). The highest of the three curves represents $15 \mathrm{~min}$. So $15 \mathrm{~min}$ appears to be a suitable time for the production of biodiesel under each of 
the tested speeds. The top of the curve $15 \mathrm{~min}$ occurs at $500 \mathrm{rpm}$. So 500 rpm stirring speed is suitable speed for the production of biodiesel at stirring time of $15 \mathrm{~min}$. Leung and Guo (2006) mentioned that the reaction time of $15 \mathrm{~min}$ is adequate to complete the production of biodiesel when using net canola oil.

\section{Effect of reaction temperature on the production of biodiesel:}

Figure (7) shows the relation between the production of biodiesel under ambient temperature $\left(30.5^{\circ} \mathrm{C}\right)$ and heating temperatures $\left(40,50\right.$ and $60^{\circ}$ C). The figure indicates that the production of biodiesel is nearly constant under the four tested temperatures. From the results of this experiment (within the tested temperature range) it is recommended to produce biodiesel under an ambient temperature of $30^{\circ} \mathrm{C}$ or more for saving heating energy. The reaction pressure gauge under the four tested temperatures had a value of 0.3 bar under reaction temperature of $60{ }^{\circ} \mathrm{C}$. This result coincides with Berrios et al. (2010). Meanwhile, for the three other temperatures, no value was detected for the pressure, Table (2).

Table (2): The pressure at each of tested temperatures.

\begin{tabular}{ccccc}
\hline Temperature, $\left({ }^{\circ} \mathbf{C}\right)$ & Room temperature $(30.5)$ & 40 & 50 & 60 \\
\hline Pressure, $($ bar $)$ & 0 & 0 & 0 & 0.3 \\
\hline
\end{tabular}

\section{Effect of the volume of the batch on the biodiesel production:}

Figure (8) shows the relationship between the production of biodiesel under different batch volumes. The figure indicates that the production of biodiesel is nearly constant under the five tested volumes. This result may be expressed as: under bench scale, the production of biodiesel is independent of the volume of the batch.

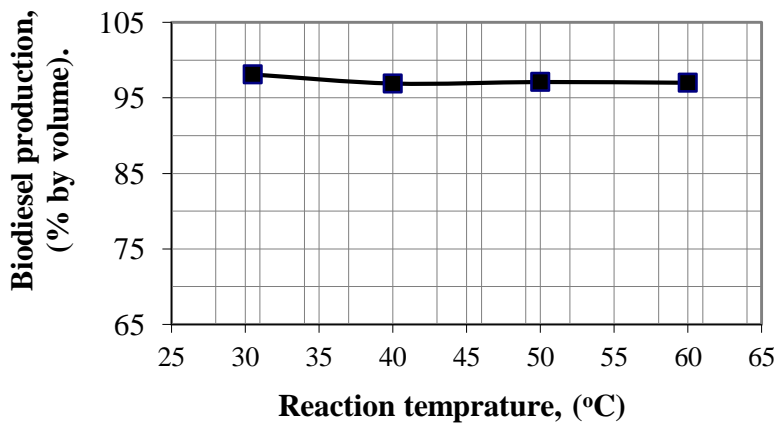

Fig. (7). The relation between biodiesel production and reaction temperature.

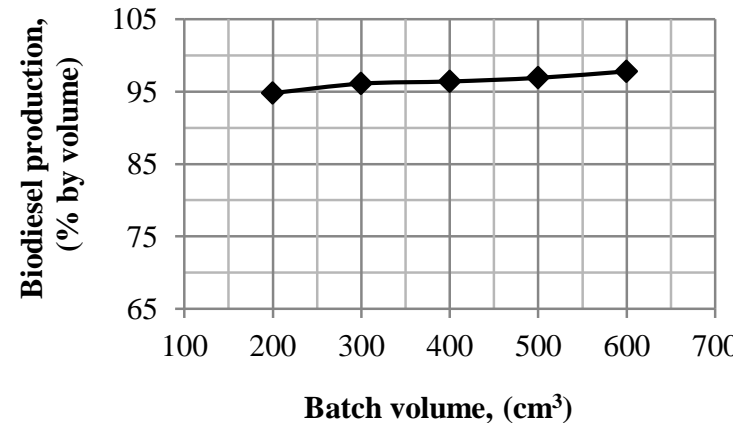

Fig. (8). The relation between production of biodiesel and batch volume. 


\section{Specifying the relative dimensions of a bench scale reactor for the production of biodiesel:}

The experiments for specifying a reactor for the production of biodiesel were carried out using the SS unit. The vessel is cylindrical in shape with height equal to diameter of the cylinder. One impeller is used. These specifications coincide with those given for standard reactors. Table (3) indicates no effect of each the three tested impellers on the production of biodiesel. Figure (9) shows no effect of the tested clearances on the production of biodiesel. Table (4) shows the production of biodiesel under each of the six tested diameter ratios. The table indicates that the diameter ratio should not be less than $1 / 2.7$, as the reaction will fail. A diameter ratio of $1 / 1.3$ decreases the production. The diameter ratios of $1 / 2.7,1 / 2$ and 1/1.6 give nearly equal biodiesel production. Diameter of impeller is effective for the production from a reactor (Reynolds number for the impeller is directly proportional to the rotational speed of the impeller and directly proportional to square diameter of the impeller). So, the mean of the three ratios $1 / 2.7,1 / 2$ and $1 / 1.6(1 / 2)$ is recommended for the production of biodiesel. This result is similar to that given for standard reactor by Tatterson (1991), cited from Jakobsen et al. (2013). Table (5) indicates that the width of the impeller (ratio) should not be less than $1 / 8$, as the reaction will fail. For the rest of the five tested widths, $1 / 8,1 / 6.4$ and $1 / 5.3$, the production of biodiesel is nearly the same. Figure (10) indicates that adding a baffle to the unbaffled (originally constructed for the experiments) does not affect the production of biodiesel.

The previous discussion leads to, from the point of view of the cost of the construction of a reactor:

(1) The impeller is of paddle type.

(2) The clearance ratio is $1 / 5.3$

(3) The diameter ratio of impeller is $1 / 2$

(4) The width ratio of impeller is $1 / 8$

(5) The reactor is unbaffled. 
Table (3) the production of biodiesel for the tested impeller shapes.

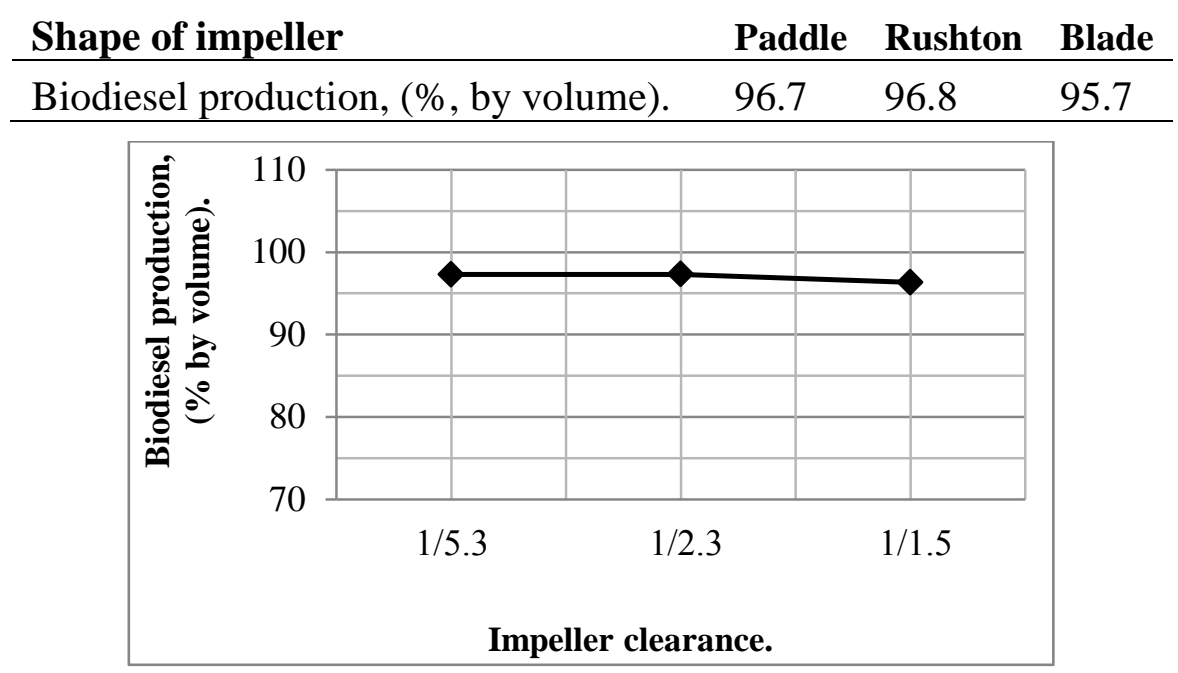

Fig. (9). The relation between production of biodiesel and impeller clearance.

Table (4). Production of biodiesel under six tested impeller diameters.

\begin{tabular}{lllllll} 
Ratio of impeller diameter. & $1 / 4$ & $1 / 3.2$ & $1 / 2.7$ & $1 / 2$ & $1 / 1.6$ & $1 / 1.3$ \\
\hline
\end{tabular}

Biodiesel production,

(\%, by volume).

$\begin{array}{llll}97.8 & 97.3 & 97.6 & 96.2\end{array}$

Table (5). Biodiesel production under five tested impeller widths.

Ratio of impeller width $\begin{array}{lllll}1 / 16 & 1 / 10.7 & 1 / 8 & 1 / 6.4 & 1 / 5.3\end{array}$

Biodiesel production, (\%, by volume).

$\begin{array}{lll}97.8 & 98.0 & 97.1\end{array}$

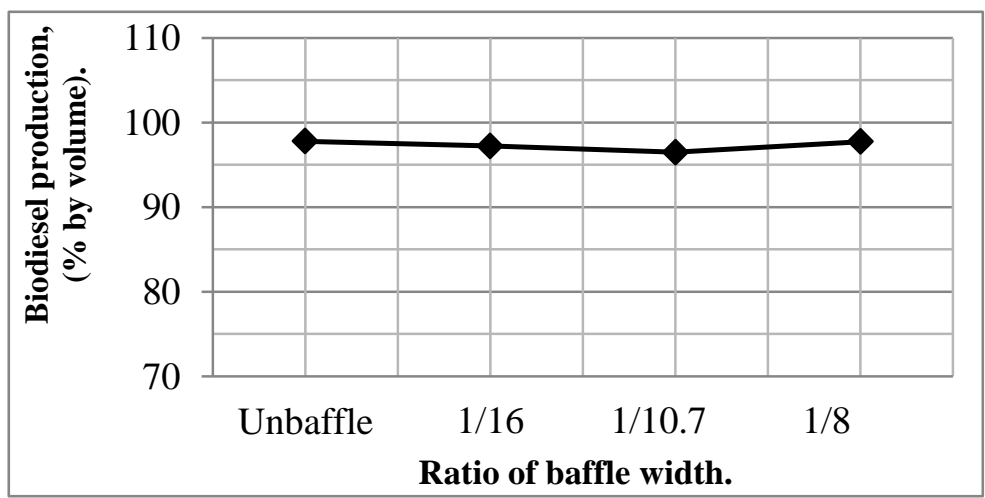

Fig. (10). The relation between production of biodiesel, (\% by volume) and ratio of baffle width. 
Table (6): Specification of the used oil through the experiments and the produced biodiesel

\begin{tabular}{ccccc}
\hline \multirow{2}{*}{ WVO used } & property & Method of tests & Result & Unit \\
\cline { 2 - 5 } & Kinematic viscosity & ASTM D-445 & 31.43 & $\mathrm{cSt}$ \\
\hline \multirow{2}{*}{$\begin{array}{c}\text { produced } \\
\text { biodiesel }\end{array}$} & Kinematic viscosity & ASTM D-445 & 4.44 & $\mathrm{cSt}$ \\
\cline { 2 - 5 } & Total acid number & ASTM D-664 & 0.48 & $\mathrm{mg} \mathrm{KOH} / \mathrm{g}$ \\
\cline { 2 - 5 } & Calorific value & ASTM D-240 & 44.8 & $\mathrm{MJ} / \mathrm{kg}$ \\
\hline
\end{tabular}

\section{SUMMARY CONCLUSION}

Biodiesel was produced using a waste vegetable oil "WVO". This oil (when virgin) is a mixture of two virgin vegetable oils: soybean and sunflower oils "in ratio 1:1". This oil is distributed by the Ministry of supply and internal trade. This oil was used in frying either domestic food such as potatoes and falafel (طعية) from 3 to 5 times or frying fish once. Methyl alcohol was used for the production of biodiesel with sodium hydroxide as a catalyst.

This study aims to investigate the specification required for the production of biodiesel under batch system and bench scale. These specifications are: (1). Ratios of the reactants (oil, alcohol and catalyst). (2). Speed and time of stirring. (3) Temperature. (4) Volume of batch. (5) Relative dimensions of the stirred vessel (reactor) used for the production of biodiesel. The specifications (1) and (2) were investigated using a PVC stirred vessel. The specifications (3), (4) and (5) were investigated using a tight stainless steel stirred vessel (reactor). This is cylindrical in shape and its height is equal to its diameter and equipped with one impeller.

\section{This study ended with:}

1. (a) The ratio of alcohol to oil $=1 / 4: 1(\mathrm{v} / \mathrm{v})$.

(b) The concentration of $\mathrm{NaOH}$ in oil is $1 \mathrm{~g} / 100 \mathrm{~cm}^{3}$.

2. Speed and time of stirring are $500 \mathrm{rpm}$ and $15 \mathrm{~min}$ respectively.

3. The production of biodiesel is carried out under ambient temperature when this temperature is about $30^{\circ} \mathrm{C}$ or more 
4. No effect of volume of batch on the production of biodiesel

5. The stirred vessel (reactor) used for the production of biodiesel is without baffles and of paddle impeller and relating to the diameter of the vessel, diameter of the impeller is $1 / 2$, clearance (between axis of the impeller and bottom of the vessel ) is $1 / 5.3$ and width of blade of impeller $1 / 8$.

\section{REFERENCES}

Ahmad M., S. Rashid, M.Khan, M. Zafar, S. Sultana and S. Gulzar (2009). Optimization of base catalyzed transesterification of peanut oil biodiesel. African J. Biotec., 8 (3): 441- 446.

Arévalo B., B. Facio, A. Jiménez, E. Rogel-Hernández, and H. Espinoza-Gómez (2008). The production of biodiesel from blended commercial oil in Mexico: A Comparative Study. J. Mex. Chem. Soc., 52 (2): 136-139.

Arjun B., K. Chris and M. Rafiqul (2008). Waste cooking oil as an alternate feedstock for biodiesel production. Canada - Energies., 1: $3-18$.

Berrios M., M. Martín, A. Chica, and A. Martín (2010). Study of esterification and transesterification in biodiesel production from used frying oils in a closed system. Spain- Chem. Eng. J., 160: 473 - 479

El Diwani G., N. Attia and S. Hawash (2009). Development and evaluation of biodiesel fuel and by-products from jatropha oil. Egypt - Int. J. Environ. Sci. Tech., 6 (2): 219-224.

Encinar J., J. Gonzalez and A. Reinares (2005). Biodiesel from used frying oil. Variables affecting the yields and characteristics of the biodiesel. Ind. Eng. Chem. Res., 44 (15): 5491 - 5499.

Encinar J., J. GonzÁlez, A. Pardal and G. Martínez (2010). Transesterification of rapeseed oil with methanol in the presence of various solvents. $3^{\text {rd }}$ I. Symp. En. from Biomass and Waste Venice, Italy,: $8-11$. 
Food Balance Sheet (2012). Economic Affairs Sector, Ministry of Agriculture and Land Reclamation - in Egypt.

Guo Y., Y. Leung., and C. Koo (2002). A clean biodiesel fuel produced from recycled oils and grease trap oils. Dept. of Mec. Eng., U. Hong Kong.

Jakobsen A., M. Mork and A. Grislingås (2013). Stirred tank reactors, Lec. notes in subject SIK 2053 Reactor tec. Dept. of Chemi. Eng. -Norwegian U. of Sc. and Tec. Downloaded from: (http://www.nt.ntnu.no/users/jakobsen/TKP4145/stirred_tank_reactors.pdf).

Kuwornoo D. and J. Ahiekpor (2010). Optimization of factors affecting the production of biodiesel from crude palm kernel oil and ethanol. Ghana - J. En. \& Env., 1 (4): 675 - 682.

Lean G. (2007). Oil and gas may run short by 2015. The Independent, UK.http://www.independent.co.uk/environment/climate-change/oiland-gas-may-run-short-by-2015-say-industry-experts-458227.html

Leung D. and Y. Guo (2006). Transesterification of neat and used frying oil: Optimization for biodiesel production. China - Fuel Proc. Tec. 87: $883-890$.

Ma F., L. Clements and M. Hanna (1998). The effect of catalyst, free fatty acids, and water on transesterification of beef tallow. Trans. of the ASAE., 41(5): 1261-1264.

Math M. and G. Irfan (2007). Optimization of restaurant waste oil methyl ester yield. J. Sci. Indian Res., 66: 772 - 776.

Math M., S. Kumar and S. Chetty (2010). Optimization of biodiesel production from oil and fats with high free fatty acids. J. Sci. Indian Res., 3 (3): 318 - 321.

McCabe W. L., J. C. Smith and P. Harriott (1993). Unit Operations of Chemical Engineering, $5^{\text {th }}$ ed. McGraw-Hill, Handbk. - ch. (9): 235- 285. 
Meher L., D. Sagar, S. Naik (2006). Technical aspects of biodiesel production by transesterification. A review. India - Renewable and Sust. En. Reviews., 10 (3): 248 - 268.

Meng X., G. Chen and Y. Wang (2008). Biodiesel production from waste cooking oil via alkali catalyst and its engine test. Fuel Proc. Tech., 89 (9): 851 - 857.

Morais S., T. Mata, A. Martins, G. Pinto and C. Costa (2010). Simulation and life cycle assessment of process design alternatives for biodiesel production from waste vegetable oils. Portugal - J. Cleaner Prod., 18: 1251-1259.

Pinzi S., J. Mata-Granados, F. Lopez-Gimenez, M. Castro, M. Dorado (2011). Influence of vegetable oils fatty-acid composition on biodiesel optimization. Spain - Bioresource Tec., 102: 1059 1065.

Refaat A. A (2010). Different techniques for the production of biodiesel from waste vegetable oil. Int. J. Environ. Sci. Tech., 7 (1): 183-213.

Reyes J. F., P.E. Malverde., P.S. Melin and J.P. De Bruijn (2010). Biodiesel production in a jet flow stirred reactor., Chile - En. Fuels 89: 3093 - 3098.

Sarantopoulos I., F. Che., T. Tsoutsos., V. Bakirtzoglou., W. Azangue., D. Bienvenue and F. Ndipen (2009). An evaluation of a small-scale biodiesel production technology: Case study of Mango'o village, Center province. Cameroon - Physics and Chem. Earth., 34: 55 - 58.

Schuchardt U., R. Serchelia and R. Matheus (1998). Transesterification of vegetable oils: A review, J. Brazil. Chem. Soc., 9 (1): 199 - 210.

Shoukry H. and M. Mosallam (2010). Effect of stirring speed and reaction time on Sunflower biodiesel production. Misr J. Ag. Eng., 28 (4): 1434 - 1444.

Tatterson G. B. (1991). Fluid mixing and gas dispersion in agitated tanks, McGraw-Hill, P: 3 (C. F. Jakobsen et al. (2013)). 
Ugheoke B., D. Patrick, H. Kefas and E. Onche (2007). Determination of optimal catalyst concentration for maximum biodiesel yield from tigernut (Cyperus Esculentus) oil., Leonardo J. Sci., (10): 131 136.

Vicente G., M. Martínez and J.Aracil (2004). Integrated biodiesel production: a comparison of different homogeneous catalysts systems. Spain - Bioresource Tec.., 92: 297 - 305.

West A, D. Posarac and N. Ellis (2008). Assessment of four biodiesel production processes using HYSYS.Plant. Canada - Bioresource Technology., 99: 6587 - 6601.

\section{الملخص العربي}

إنتاج الديزل الحيوي من الزيت التباتي المخلف

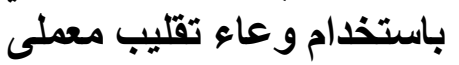

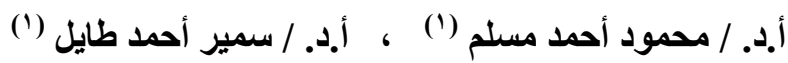

(")

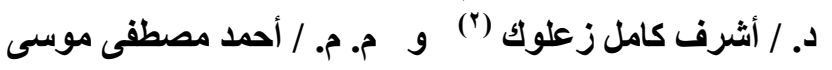

تم انتاج الديزل الحيوي باستخدام زيت نباتي مخلف. هذا الزيت (قبل القلي) هو خليط من نوعين

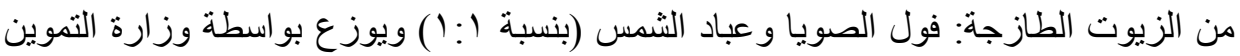

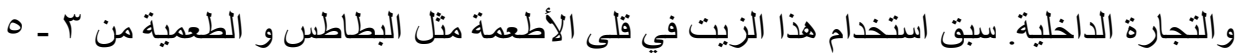

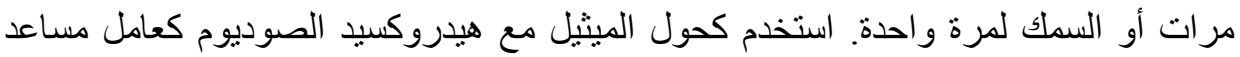
لإلنتاج الديزل الحيوي.

يهدف هذا البحث الى دراسة المواصفات اللازمة لإنتاج الديزل الحيوي بنظام الدفعة تحت

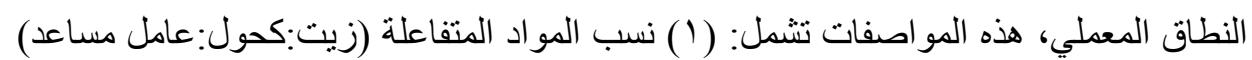

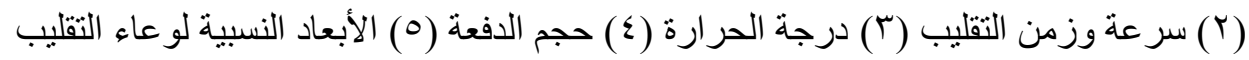

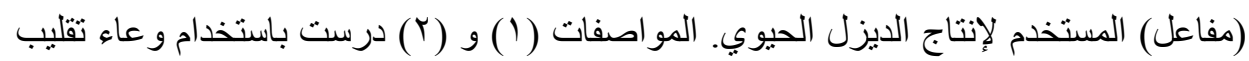

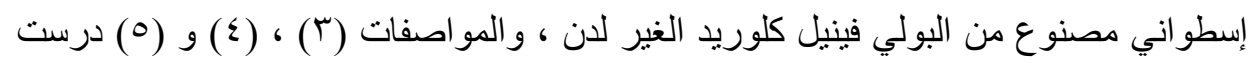

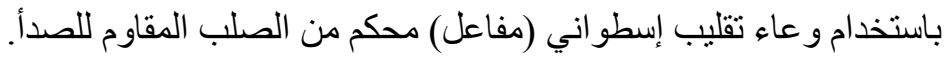

(1) أستاذ الهندسة الزراعية ـ كلية الهندسة الزراعية بالقاهرة - جامعة الأزهر.

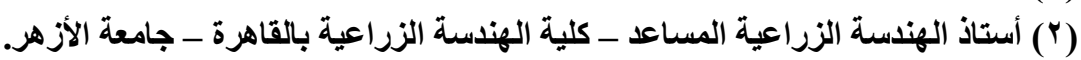

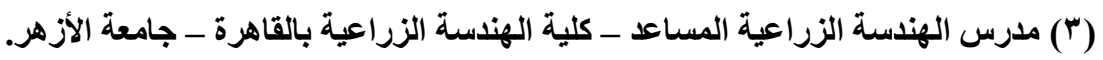




\section{انتهت الدراسة الي النتائج الموصى بها التالية:}

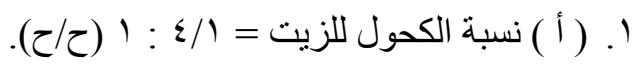

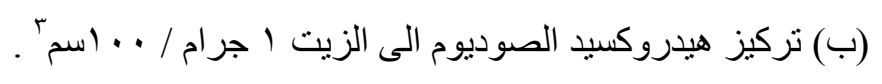

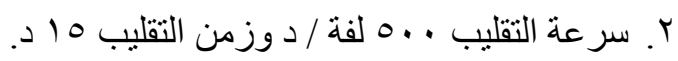
r. إنتاج الديزل الحيوي يكون على درجة حرارة الغرفة (· به م فأكثر).

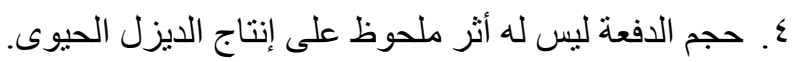

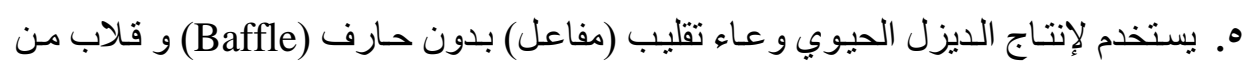

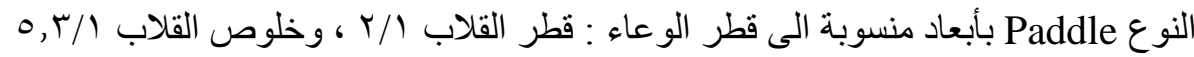

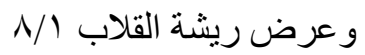

